Article

\title{
Unusual Product Distribution from Friedländer Reaction of Di- and Triacetylbenzenes with 3-Aminonaphthalene-2-carbaldehyde and Properties of New Benzo[g]quinoline-Derived Aza-aromatics
}

\author{
Moinul Karim and Yurngdong Jahng * \\ College of Pharmacy, Yeungnam University, Gyeongsan 712-749, Korea \\ * Author to whom correspondence should be addressed; E-Mail: ydjahng@ynu.ac.kr; \\ Tel.: +82-53-810-2821; Fax: +82-53-810-4654.
}

Received: 23 July 2014; in revised form: 13 August 2014 / Accepted: 14 August 2014 / Published: 21 August 2014

\begin{abstract}
The Friedländer reactions of acetylbenzenes and 2-acetylpyridine with 3-aminonaphthalene-2-carbaldehyde afforded the corresponding 2-phenylbenzo[g]quinoline and 2-(pyrid-2-yl)benzo[g]quinoline, respectively. The same reactions of 3-aminonaphthalene-2-carbaldehyde with 1,2-, 1,3-, 1,4-di- and 1,3,5-triacetylbenzenes, however, afforded a series of corresponding (benzo[g]quinolin-2-yl)benzenes as new $N, C$-bidentate and unexpected benzo[g]quinoline. Crystallinity, thermal properties, absorption and emission spectral properties of the products were studied.
\end{abstract}

Keywords: Friedländer reactions; benzo[g]quinoline; 2-phenylbenzo $[g]$ quinoline; 2-(pyrid-2-yl)benzo[g]quinoline; 1,3-di(benzo[g]quinolin-2-yl)benzene; 1,3,5-tri(benzo[g]quinolin-2-yl)benzene; $N, C$-bidentate; photoluminescence

\section{Introduction}

The 2-phenylpyridine molecule is itself a monodentate ligand, of which the initial $\mathrm{N}$-coordinated intermediate nevertheless undergoes cyclometalation of the $\mathrm{C}-\mathrm{H}$ bond at the ortho-position with a variety of metals, especially $\mathrm{d}^{4}$ and $\mathrm{d}^{6}$ metals, to form the common $\mathrm{N}^{\wedge} \mathrm{C}$-bidentate cyclometalated five-membered rings [1]. The most intriguing properties of 2-phenylpyridine, especially in the area of organic light emitting devices (OLED), result from its ability $[2,3]$ to form iridium complexes such as $\left[\operatorname{Ir}\left(\mathrm{N}^{\wedge} \mathrm{C}\right)_{3}\right]$ [4-6], $\left[\operatorname{Ir}\left(\mathrm{N}^{\wedge} \mathrm{C}\right)_{2} \mathrm{~L}\right]^{2+}\left(\mathrm{L}=\right.$ an additional $\mathrm{N}^{\wedge} \mathrm{N}-[7-9], \mathrm{N}^{\wedge} \mathrm{C}-[10], \mathrm{N}^{\wedge} \mathrm{O}-[11]$, as well as $\mathrm{O}^{\wedge} \mathrm{O}$-bidentates $[12,13]$, respectively), and $\left[\operatorname{Ir}\left(\mathrm{N}^{\wedge} \mathrm{C}\right)\left(\mathrm{N}^{\wedge} \mathrm{N}^{\wedge} \mathrm{N}\right) \mathrm{L}\right]^{+}$(where $\mathrm{L}$ is an anionic monodentate 
ligand) [14]. 2-Phenylquinoline [15,16] and 2-phenylbenzo[g]quinoline (3aa) [17,18] have been introduced as benzo-fused analogs of 2-phenylpyridine to improve the luminescence intensity, efficiency, and/or lifetime. However, systematic studies on the preparation of the systems with benzo[g]quinoline (BQ) have not been pursued as yet.

The preparation methods of $\mathbf{3 a a}$ found in the literature, included a Grignard reaction of benzo[g]quinoline with phenylmagnesium bromide [19,20], a Pfitzinger reaction of 5,6-benzoisatin and acetone [21], a Friedländer reaction of acetophenone and 3-aminonaphthalene-2-carbaldehyde [22], and an electrophilic cyclization of 2-azido-3-(3-phenylprop-2-yn-1-yl)naphthalene [23]. The Friedländer reaction has, however, been one of the most effective methods for quinoline-based heterocycles, even though the preparation of some prerequisite $o$-aminoarenecarbaldehydes requires somewhat lengthy reaction sequence [24].

As a part of our interest in azapolyaromatics [25], we describe herein Friedländer reactions of acetylbenzene and polyacetylbenzenes with 3-aminonaphthalene-2-carbaldehyde for the synthesis of a series of benzo[ $g]$ quinoline-derived aza-aromatics and some properties of the resulting products.

\section{Results and Discussion}

\subsection{Synthesis}

Synthesis of the designed compounds was straightforward as shown in Scheme 1. The Friedländer reactions of a series of acetylbenzenes 1 with 3-aminonaphthalene-2-carbaldehyde (2) in the presence of $\mathrm{KOH}$ afforded the desired products 3 in 12\%-72\% yields, except for $\mathbf{1 b}$. Although reactions of acetylbenzene (1aa) and 2-acetylpyridine (1ab) with $\mathbf{2}$ afforded the Friedländer adducts 3aa and 3ab [26] in $72 \%$ and $86 \%$ yield, respectively, with a trace of as yet unidentifiable products, reactions of diacetylbenzenes 1b, 1c and 1d led somewhat unexpected results. The reactions between 1,2-diacetylbenzene (1b) and $\mathbf{2}$ resulted in formation of benzo[ $g$ ]quinoline (4) in $40 \%$ yield as a major products without any trace of the expected $\mathbf{3 b}$, while the reactions of 1,3- (1c) and 1,4-diacetylbenzene (1d) afforded the desired Friedländer products $\mathbf{3 c}$ and $\mathbf{3 d}$ in $63 \%$ and $12 \%$, respectively, along with 4 in $24 \%$ and $33 \%$, respectively. It should be noted that the reaction of $1 \mathbf{d}$ with excess (2.2 equiv.) 2 afforded the monocondensed 1-(benzo[g]quinolin-2-yl)-4-acetylbenzene (5) in 45\% yield, which also led to formation of $\mathbf{3 d}$ and $\mathbf{4}$ in a similar ratio by subsequent Friedländer reaction with additional 2. The structure of $\mathbf{4}$ was confirmed by physical properties and comparison to the spectral data in the literature [27]. ${ }^{1} \mathrm{H}-\mathrm{NMR}$ showed two characteristic resonances for $\mathrm{H}_{2}$ and $\mathrm{H}_{3}$ of BQ moiety as a doublet of doublets at $\delta 8.97\left(J_{2,3}=4.3, J_{2,3}=1.2 \mathrm{~Hz}\right)$ for $\mathrm{H}_{2}$ and $\delta 7.35\left(J_{3,4}=8.5, J_{2,3}=4.3 \mathrm{~Hz}\right)$ for $\mathrm{H}_{3}$, respectively. Although the Friedländer reaction of $\mathbf{1 b}$ with 4-aminoacridine-3-carbaldehyde [28] and the reactions of triacetylmethane with o-aminoarenecarbaldehydes [29] resulted in similar type of unexpected products, a possible reaction mechanism for 4 remains to be clarified. 
Scheme1. Synthesis of benzo[ $g]$ quinoline-derived azaaromatics.

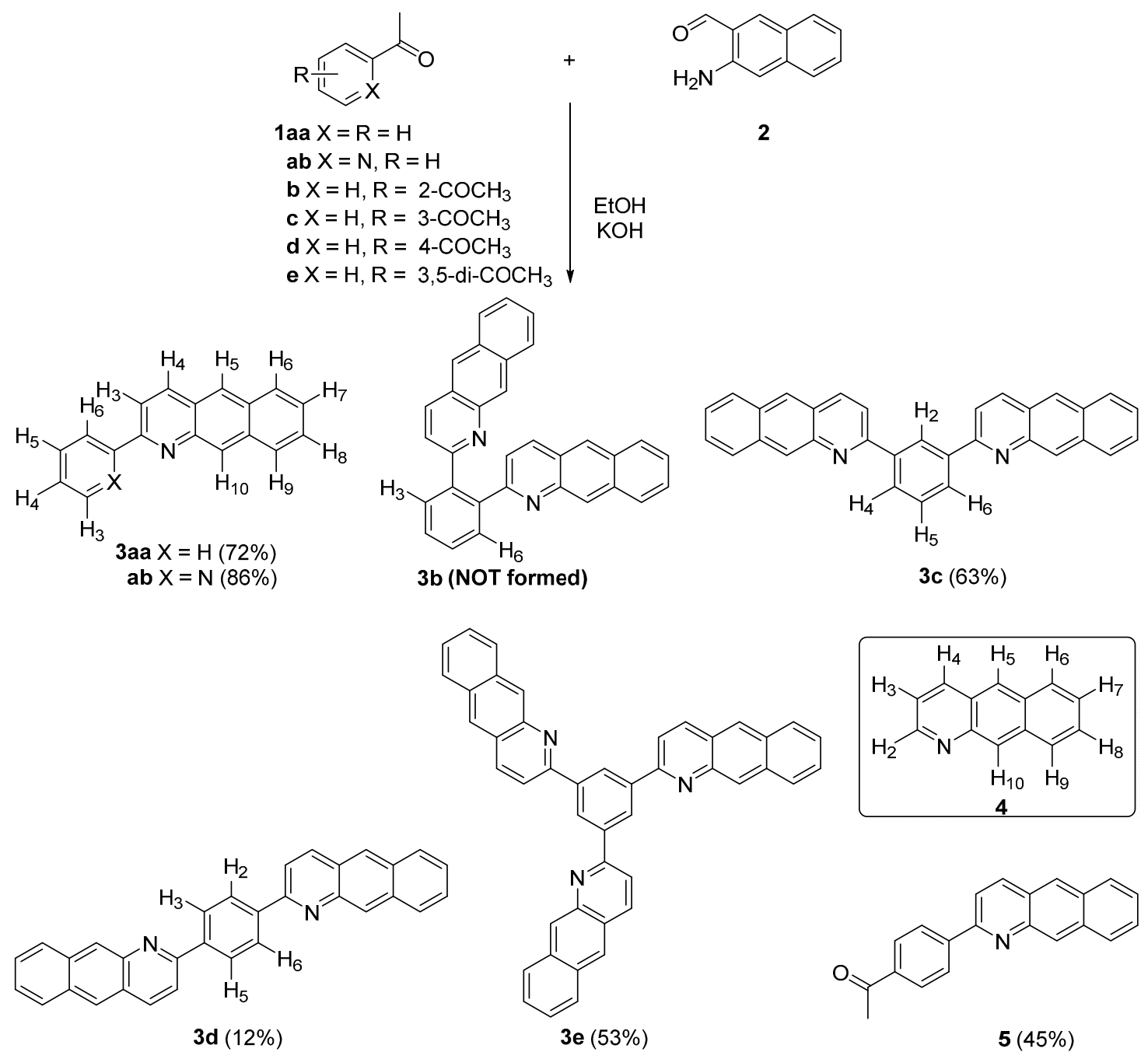

\subsection{Spectroscopic Properties}

The ligands prepared could be readily characterized by ${ }^{1} \mathrm{H}-\mathrm{NMR}$ spectral data and electrospray ionization mass spectrometry. Selected proton resonances are summarized in Table 1. Even though it was not always possible to completely resolve and assign all the proton resonances, certain features were characteristic and diagnostic enough to provide crucial clues about the structures. Typically, $\mathrm{H}_{5}$ and $\mathrm{H}_{10}$ of the benzo[g]quinoline (BQ) moiety and $\mathrm{H}_{2}\left(\right.$ and/or $\left.\mathrm{H}_{6}\right)$ in the phenyl $(\mathrm{Ph})$ ring of 3 are the ones to allow easy assignment by comparing their chemical shifts and splitting patterns as well as numbers of protons. In 3aa, $\mathrm{H}_{5}$ and $\mathrm{H}_{10}$ of $\mathrm{BQ}$ were resonated at $\delta 8.65$ and 8.76 as an one-proton singlet, respectively, while $\mathrm{H}_{2}$ and $\mathrm{H}_{6}$ of $\mathrm{Ph}$ at $\delta 8.36$ as a two-proton doublet of doublet $(J=8.1,1.2 \mathrm{~Hz})$. Introducing an additional $\mathrm{BQ}$ moiety on benzene ring usually resulted in downfield-shift of these protons. Introduction of BQ moiety to $\mathrm{C}_{3}$ of the central benzene ring led to significant shift of $\mathrm{H}_{2}$ of $\mathrm{Ph}$ by $0.76 \mathrm{ppm}$ resonating at $\delta 9.12$ as a one-proton triplet $(J=0.8 \mathrm{~Hz})$. In tri-substituted system $3 \mathbf{e}, \mathrm{H}_{2}$ of $\mathrm{Ph}$ was resonated at $\delta 9.30$ as a three-proton singlet due to the two adjacent $\mathrm{N}_{1}$ 's of BQ moiety that is comparable to those of 1,3,5-tri(azaheteroar-2-yl)benzenes [28,30]. 
Table 1. Selected proton resonances for compounds 3, 4 and 5 .

\begin{tabular}{cccccccc}
\hline & $\mathbf{H}_{\mathbf{2}}$ of $\mathbf{P h}$ & $\mathbf{H}_{\mathbf{3}}$ of $\mathbf{P h}$ & $\mathbf{H}_{\mathbf{2}}$ of $\mathbf{B Q}$ & $\mathbf{H}_{\mathbf{3}}$ of $\mathbf{B Q}$ & $\mathbf{H}_{\mathbf{4}}$ of $\mathbf{B Q}$ & $\mathbf{H}_{\mathbf{5}}$ of $\mathbf{B Q}$ & $\mathbf{H}_{\mathbf{1 0}} \mathbf{~ o f ~} \mathbf{B Q}$ \\
\hline $\mathbf{3 a a}$ & 8.24 & 7.89 & - & - & 8.38 & 8.40 & 8.77 \\
$\mathbf{3 a b}$ & - & $8.74^{\mathrm{a}}$ & - & 8.57 & 8.46 & 8.44 & 8.79 \\
$\mathbf{3 c}$ & 9.12 & 8.40 & - & - & 8.46 & 8.43 & 8.70 \\
$\mathbf{3 e}$ & 9.30 & 8.25 & - & - & 8.52 & 8.48 & 8.90 \\
$\mathbf{4}$ & - & - & 8.97 & 7.35 & 8.58 & 8.40 & 8.76 \\
$\mathbf{5}$ & 8.51 & $8.26-8.15$ & - & $8.26-8.15$ & 8.689 & 8.69 & 8.81 \\
\hline \multicolumn{7}{c}{ Note: $^{\text {a }}$ This resonance corresponds to $\mathrm{H}_{3}$ of the pyridine moiety of 3ab. }
\end{tabular}

UV absorption spectra of $\mathbf{3}$ and $\mathbf{5}$, and the parent $\mathbf{4}$ in EtOH $\left(1 \times 10^{-5} \mathrm{~mol} / \mathrm{L}\right)$ were investigated, and the data are given in Figure 1 and Table 2. All compounds display intense absorption bands in the ultraviolet region 205-400 $\mathrm{nm}$ with extinction coefficients $(\varepsilon)$ of $\sim 10^{5}$, which are assigned to spin-allowed ${ }^{1} \mathrm{LC}$ transitions.

Table 2. UV absorption and emission spectral data of 3, 4 and 5.

\begin{tabular}{cccc}
\hline Compound & $\boldsymbol{\lambda}_{\text {abs/nm }}(\log \varepsilon)$ & $\lambda_{\text {excit }}$ & $\boldsymbol{\lambda}_{\text {em }}$ \\
\hline 3aa & $205(4.86) 228(4.63) 257(\mathrm{~s}, 4.60) 282(4.91) 352(3.81) 371(3.96)$ & 282 & 481 \\
$\mathbf{3 a b}^{\text {a }}$ & $204(4.70) 225(4.83) 259(\mathrm{~s}, 4.78) 287(4.98) 351(4.04) 370(4.15)$ & 225 & 488 \\
$\mathbf{3 c}$ & $205(5.00) 228(\mathrm{~s}, 4.80) 265(\mathrm{~s}, 4.76) 286(4.86) 371(3.88)$ & 286 & 470 \\
$\mathbf{3 e}$ & $209(\mathrm{~s}, 4.78) 216(4.81) 249(4.36) 294(4.28) 378(3.43)$ & 294 & 470 \\
$\mathbf{4}$ & $203(4.30) 227(4.46) 253(4.88) 272(\mathrm{~s}, 4.08) 358(3.66)$ & 253 & 435 \\
$\mathbf{5}$ & $205(4.83) 216(4.88) 232(\mathrm{~s}, 4.76) 246(4.72) 298(4.90)$ & 298 & 470 \\
\hline
\end{tabular}

Note: ${ }^{a}$ Excitation of the absorbance at $287 \mathrm{~nm}$ did not show any observable emission.

Figure 1. UV absorption and photoluminescence (PL) spectra of 3, 4, and $\mathbf{5}$ in EtOH $\left(1 \times 10^{-5} \mathrm{M}\right)$ at $298 \mathrm{~K}$. In PL spectra emission of $\mathbf{3 a b}$ was overlapped with that of $\mathbf{5}$, thus omitted for clarity.

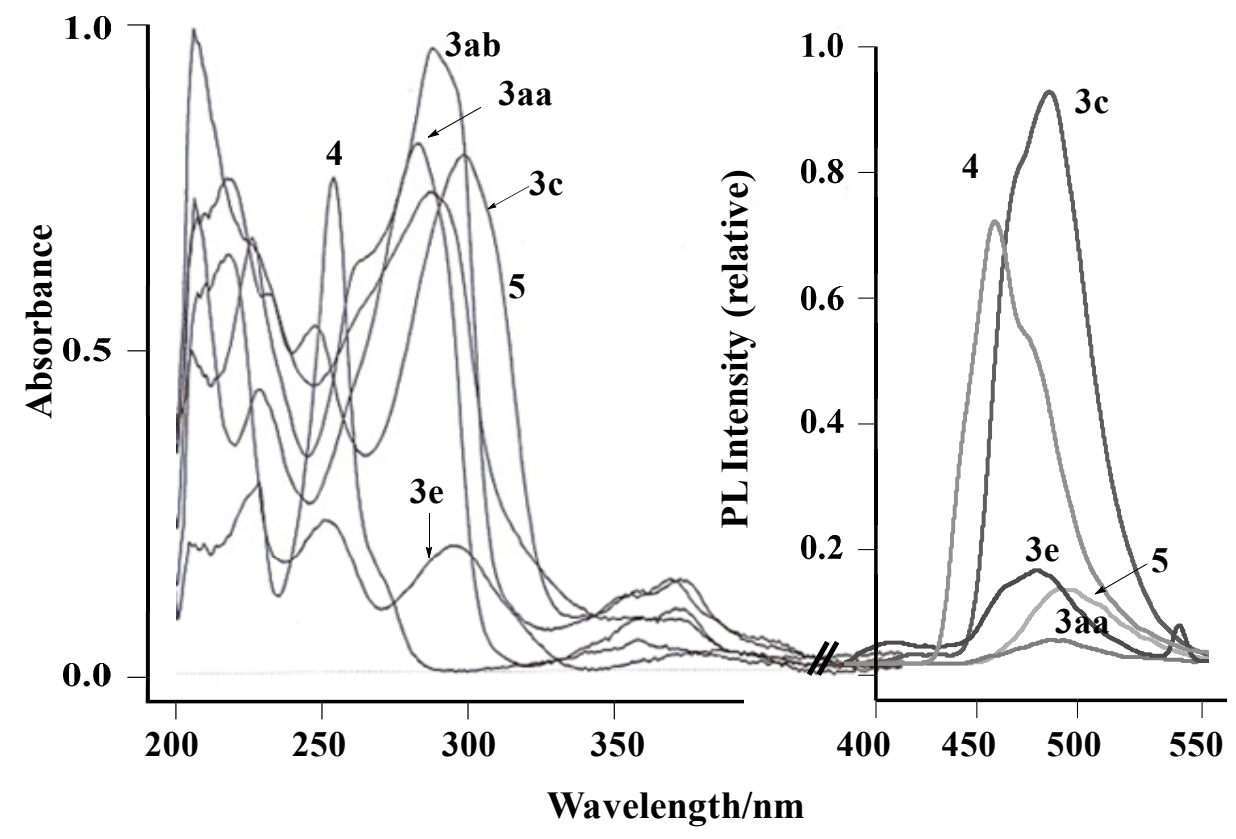


The photoluminescence (PL) of the compounds was studied in EtOH $\left(1 \times 10^{-5} \mathrm{~mol} / \mathrm{L}\right)$ at room temperature and are given in Table 2. Excitation of the absorbance in the region 253-294 nm showed greenish blue light emissions in the range of 470-488 $\mathrm{nm}$. The observed emission wavelength is somewhat dependent on the nature of the central benzene ring: Disubstituted ligands (3c, 3e, 5) showed emissions at $470 \mathrm{~nm}$ while monosubstituted ones (compounds 3aa, 3ab) showed them at 481 and $488 \mathrm{~nm}$. The parent benzo[g]quinoline showed blue light emission at $435 \mathrm{~nm}$. It should be noted that the emission of $\mathbf{3 c}$ and $\mathbf{3 e}$ were the relatively high compared to those (Figure 1).

\subsection{Thermal and Structural Properties}

The thermal behaviors of the compounds were analyzed by differential scanning calorimetry (DSC). All the compounds showed a single sharp endothermic peak at the melting transition temperature $\left(T_{\mathrm{m}}\right)$ and exothermic peaks at the crystallization temperature $\left(T_{\mathrm{c}}\right)$ as shown in Figure 2. However, none of the compounds showed glass transition temperature $\left(T_{\mathrm{g}}\right)$. It should be noted that compounds $\mathbf{3 a a}$ and $\mathbf{5}$ showed temperature increasing during crystallization implying that super cooling may be accompanied during crystallization. As a result, all the compounds prepared have good thermal stability despite of being relatively low molecular weight organic compounds.

The crystallinity of the compounds prepared was analyzed by XRD (X-ray diffraction) and X-ray diffractograms are shown in Figure 3. All of X-ray diffractograms of the compounds showed numerous distinctive peaks indicating their crystalline nature.

Figure 2. DSC of $\mathbf{3 a a}$ and $\mathbf{3 c}$.

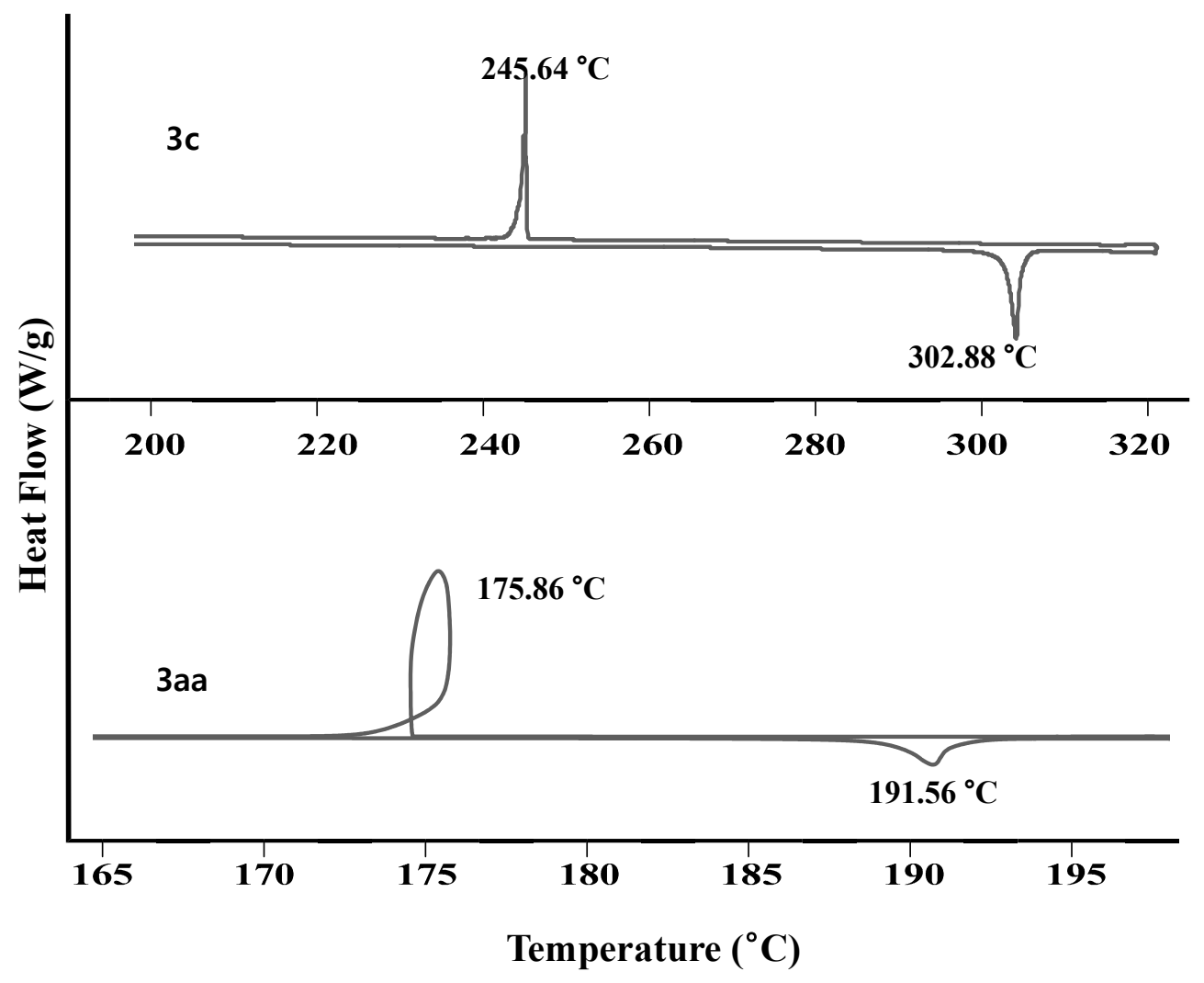


Figure 3. X-ray diffractograms of compounds prepared in powder state.

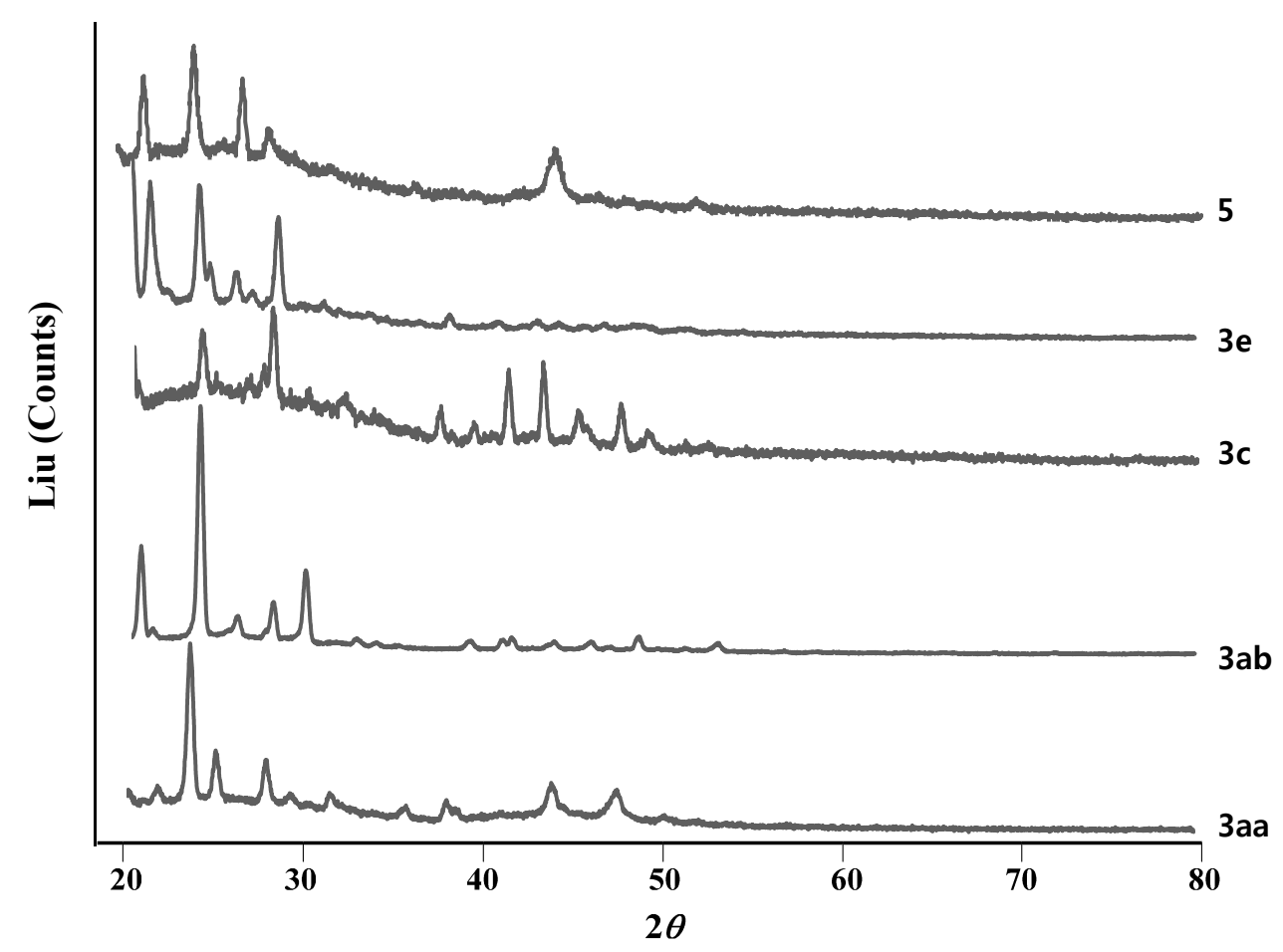

\section{Experimental Section}

\section{General Information}

Melting points were determined using a Fischer-Jones melting points apparatus and are not corrected. UV spectra were recorded on a V550 spectrophotometer (Jasco, Tokyo, Japan). IR spectra were obtained using a 1330 spectrophotometer (Perkin-Elmer, city, state abbrev if US, country). NMR spectra were obtained using a Bruker-250 spectrometer (Fällanden, Switzerland) or VNS600 FT-NMR (Varian, Australia) for ${ }^{1} \mathrm{H}-\mathrm{NMR}$ and $62.5 \mathrm{MHz}$ for ${ }^{13} \mathrm{C}$-NMR and are reported as parts per million (ppm) from the internal standard TMS. Chemicals and solvents were commercial reagent grade and used without further purification. Electrospray ionization (ESI) mass spectrometry (MS) experiments were performed on a LCQ advantage-trap mass spectrometer (Thermo Finnigan, San Jose, CA, USA). Elemental analyses were taken on a Hewlett-Packard Model 185B CHN analyzer (Hewlett Packard, Littleton, MA, USA). XRD analysis was performed by X-ray Diffractometer (Model: MPD for bulk, PANalytical, Wesybrough, MA, USA) with nickel-filtered $\mathrm{CuK} \alpha$ radiation $(30 \mathrm{kV}, 30 \mathrm{~mA})$ at $2 \theta$ angles from $10^{\circ}$ to $90^{\circ}$, a scan speed of $10^{\circ} / \mathrm{min}$ and a time constant of $1 \mathrm{~s}$. Thermal behaviors of the compounds were analyzed using differential scanning calorimetty (DSC Q200, TA Instrument, Wilminton, NJ, USA) with 1 2 mg of sample sealed in alumina in the range of $40-385{ }^{\circ} \mathrm{C}$ increasing temperature in a rate of $10{ }^{\circ} \mathrm{C} / \mathrm{min}$. An empty pan was used as a reference, and the DSC baseline, temperature, and enthalpy were calibrated. Starting 3-material aminonaphthalene-2-carbaldehyde (2) was prepared employing a previously reported method [15]. 
2-Phenylbenzo[g]quinoline (3aa). To a solution of an equimolar of acetylbenzene (1aa, $70 \mathrm{mg}, 0.58 \mathrm{mmol})$ and $2(100 \mathrm{mg}, 0.58 \mathrm{mmol})$ in $\mathrm{EtOH}(40 \mathrm{~mL})$ was added saturated $\mathrm{KOH}$ in EtOH $(0.5-1 \mathrm{~mL})$. The resulting reaction mixture was refluxed for $15 \mathrm{~h}$. Evaporation of the solvent resulted in solid material which was chromatographed on silica gel eluting with $\mathrm{CH}_{2} \mathrm{Cl}_{2}$. The latter fractions $\left[R_{\mathrm{f}}=0.42\right.$, $\mathrm{CH}_{2} \mathrm{Cl}_{2}$ :EtOAc (5:1)] afforded the desired product (106 mg, 72\%): mp 193-195 ${ }^{\circ} \mathrm{C} \mathrm{(lit.} \mathrm{[11a]} \mathrm{mp} 188{ }^{\circ} \mathrm{C}$; lit. [13] mp 190-192 ${ }^{\circ} \mathrm{C}$ ). Tc $175.85^{\circ} \mathrm{C} .{ }^{1} \mathrm{H}-\mathrm{NMR}\left(600 \mathrm{MHz}, \mathrm{CDCl}_{3}\right) \delta 8.77$ (s, 1H, $\mathrm{H}_{10}$ of BQ), 8.40 (s, $1 \mathrm{H}, \mathrm{H}_{5}$ of BQ), 8.39 (d, $1 \mathrm{H}, J=9.0 \mathrm{~Hz}, \mathrm{H}_{4}$ of BQ), 8.24 (dd, $2 \mathrm{H}, J=8.1,1.2 \mathrm{~Hz}, \mathrm{H}_{2}$ and $\mathrm{H}_{6}$ of $\mathrm{Ph}$ ), 8.10 (dd, $1 \mathrm{H}, J=7.2,0.8 \mathrm{~Hz}, \mathrm{H}_{6} / \mathrm{H}_{9}$ of BQ), 8.03 (dd, $1 \mathrm{H}, J=7.2,1.8 \mathrm{~Hz}, \mathrm{H}_{9} / \mathrm{H}_{6}$ of BQ), 7.89 (d, $1 \mathrm{H}$, $J=9.0 \mathrm{~Hz}, \mathrm{H}_{3}$ of $\left.\mathrm{BQ}\right), 7.57-7.46\left(\mathrm{~m}, 5 \mathrm{H}, \mathrm{H}_{7}, \mathrm{H}_{8}\right.$ of $\mathrm{BQ}, \mathrm{H}_{3}, \mathrm{H}_{4}, \mathrm{H}_{5}$ of $\left.\mathrm{Ph}\right) .{ }^{13} \mathrm{C}-\mathrm{NMR}(62.5 \mathrm{MHz}$, DMSO- $\left.d_{6}\right) \delta 157.99,145.25,139.83,138.66,134.93,132.48,131.09,130.08,129.43,129.33,128.56$, $127.97,127.84,127.65,127.28,126.55,119.78$.

2-(Pyridin-2-yl)benzo[g]quinoline (3ab). Pale yellow needles $\left[86 \%, R_{\mathrm{f}}=0.38, \mathrm{CH}_{2} \mathrm{Cl}_{2}\right.$ :EtOAc (4:1)]: mp 149-151 ${ }^{\circ} \mathrm{C}$ (lit. ${ }^{21} \mathrm{mp} 145-150{ }^{\circ} \mathrm{C}$ ). Tc $113.38{ }^{\circ} \mathrm{C}$. Unreported spectral data are as follows: ${ }^{1} \mathrm{H}-\mathrm{NMR}\left(250 \mathrm{MHz}, \mathrm{CDCl}_{3}\right) \delta 8.79\left(\mathrm{~s}, 1 \mathrm{H}, \mathrm{H}_{10}\right.$ of $\left.\mathrm{BQ}\right), 8.77\left(\mathrm{dd}, 1 \mathrm{H}, J=4.8,2.1 \mathrm{~Hz}, \mathrm{H}_{6}\right.$ of py), $8.74\left(\mathrm{dd}, 1 \mathrm{H}, J=8.7,1.2 \mathrm{~Hz}, \mathrm{H}_{3}\right.$ of py), 8.57 (d, $1 \mathrm{H}, J=8.9 \mathrm{~Hz}, \mathrm{H}_{3}$ of BQ), 8.46 (d, $1 \mathrm{H}, J=8.7 \mathrm{~Hz}, \mathrm{H}_{4}$ of BQ), 8.14-8.04 (m, 2H, $\mathrm{H}_{6}$ and $\mathrm{H}_{9}$ of BQ), $7.92\left(9 \mathrm{td}, 1 \mathrm{H}, J=8.0,1.8 \mathrm{~Hz}, \mathrm{H}_{4}\right.$ of py), 7.56-7.52 (m, $2 \mathrm{H}, \mathrm{H}_{7}$ and $\mathrm{H}_{8}$ of $\left.\mathrm{BQ}\right), 7.40$ (ddd, $1 \mathrm{H}, J=8.0,4.8,1.0 \mathrm{~Hz}, \mathrm{H} 5$ of py). ${ }^{13} \mathrm{C}-\mathrm{NMR}\left(62.5 \mathrm{MHz}, \mathrm{CDCl}_{3}\right) \delta$ $157.05,156.41,149.35,144.55,137.25,137.16,134.23,132.21,128.72,128.33,127.95,126.62$, 126.58, 126.41, 126.31, 124.43, 122.21, 118.78. MS (ESI) cacld for $\mathrm{C}_{18} \mathrm{H}_{13} \mathrm{~N}_{2}[\mathrm{M}+1] 257$, found 257. Anal. calcd for $\mathrm{C}_{18} \mathrm{H}_{12} \mathrm{~N}_{2} \mathrm{C}, 84.35 ; \mathrm{H}, 4.72 ; \mathrm{N}, 10.93$. Found C, 83.69; H, 4.80; N, 11.23.

1,2-Bis(benzo[g]quinolin-2-yl)benzene (3b). The same procedure described above for 3aa was applied to 1,2-diacetylbenzene (1b) to produce an as yet unidentifiable product $(\sim 30 \%)$ along with known benzo[g]quinoline (4): Pale yellow needles [40\%, $R_{\mathrm{f}}=0.4\left(\mathrm{CH}_{2} \mathrm{Cl}_{2}\right.$ :EtOAc $\left.\left.=3: 1\right)\right]$ : mp $110-112{ }^{\circ} \mathrm{C}$ (lit. [17] mp $108-109{ }^{\circ} \mathrm{C}$ Spectral $\left({ }^{1} \mathrm{H}\right.$ - and ${ }^{13} \mathrm{C}-\mathrm{NMR}$ and IR) data were identical to those reported previously.

1,3-Bis(benzo[g]quinolin-2-yl)benzene (3c). Pale yellow needles $\left[63 \%, R_{\mathrm{f}}=0.46, \mathrm{CH}_{2} \mathrm{Cl}_{2}: \mathrm{EtOAc}\right.$ (4:1)]: mp 308-311 ${ }^{\circ} \mathrm{C} . T \mathrm{c} 245.64{ }^{\circ} \mathrm{C} .{ }^{1} \mathrm{H}-\mathrm{NMR}\left(250 \mathrm{MHz}, \mathrm{CDCl}_{3}\right) \delta 9.12(\mathrm{t}, 1 \mathrm{H} J=0.8 \mathrm{~Hz}, \mathrm{H} 2$ and $\mathrm{H} 5$ of $\mathrm{Ph}$ ), 8.83 (s, 2H, $\mathrm{H}_{10}$ of BQ), 8.46 (d, 2H, $J=9.0 \mathrm{~Hz}, \mathrm{H}_{4}$ of BQ), 8.44 (s, 2H, $\mathrm{H}_{5}$ of BQ), 8.40 (dd, $2 \mathrm{H}, J=7.8,1.8 \mathrm{~Hz}, \mathrm{H}_{3}$ and $\mathrm{H}_{6}$ of $\mathrm{Ph}$ ), 8.14-8.05 (m, 4H, $\mathrm{H}_{6}$ and $\mathrm{H}_{9}$ of BQ), 8.06 (d, 2H, $J=9.0 \mathrm{~Hz}, \mathrm{H}_{3}$ of BQ), 7.75 (t, $1 \mathrm{H}, J=7.5 \mathrm{~Hz}, \mathrm{H}_{5}$ of $\left.\mathrm{Ph}\right), 7.57-7.49$ (m, 4H, $\mathrm{H}_{7}$ and $\mathrm{H}_{8}$ of BQ).

${ }^{13} \mathrm{C}-\mathrm{NMR}\left(62.5 \mathrm{MHz}, \mathrm{CDCl}_{3}\right) \delta 157.86,145.04,140.52,137.43,134.54,132.13,129.72,129.13$, 128.82 , 128.40, 127.96, 127.28, 126.61, 126.60, 126.22, 126.00, 119.19. MS (ESI) cacld for $\mathrm{C}_{32} \mathrm{H}_{21} \mathrm{~N}_{2}$ $[\mathrm{M}+1]$ 433, found 433. Anal. calcd for $\mathrm{C}_{32} \mathrm{H}_{20} \mathrm{~N}_{2} \mathrm{C}, 88.86 ; \mathrm{H}, 4.66 ; \mathrm{N}, 6.48$. Found C, 89.09; H, 4.58; $\mathrm{N}, 6.53$. Benzo[g]quinoline (4): $24 \%$.

1,4-Bis(benzo[g]quinolin-2-yl)benzene (3d). Pale yellow needles (12\%) were obtained from a reaction mixture as precipitate: $\mathrm{mp}>300{ }^{\circ} \mathrm{C}$. This compound is not soluble either common organic solvents or $\mathrm{HCl}$ and thus unable to get spectral data Anal. calcd for $\mathrm{C}_{32} \mathrm{H}_{20} \mathrm{~N}_{2} \mathrm{C}, 88.86 ; \mathrm{H}, 4.66 ; \mathrm{N}, 6.48$. Found C, 88.97; H, 4.60; N, 6.43. 1-[4-(Benzo[g]quinolin-2-yl)phenyl]ethan-1-one (5): Pale yellow needles $\left[45 \%, R_{\mathrm{f}}=0.65\left(\mathrm{CH}_{2} \mathrm{Cl}_{2}: \mathrm{EtOAc}=3: 1\right)\right]: \mathrm{mp} 225-227{ }^{\circ} \mathrm{C} . \mathrm{Tc} 197.73{ }^{\circ} \mathrm{C}$. IR $(\mathrm{KBr})$ v $1678 \mathrm{~cm}^{-1}$. 
${ }^{1} \mathrm{H}-\mathrm{NMR}\left(250 \mathrm{MHz}, \mathrm{DMSO}-d_{6}\right) \delta 8.81\left(\mathrm{~s}, 1 \mathrm{H}, \mathrm{H}_{10}\right.$ of BQ), $8.69\left(\mathrm{~s}, 1 \mathrm{H}, \mathrm{H}_{5}\right.$ of BQ), $8.689(\mathrm{~d}, 1 \mathrm{H}$, $J=9.0 \mathrm{~Hz}, \mathrm{H}_{4}$ of BQ), $8.51\left(\mathrm{~d}, 2 \mathrm{H}, J=8.8 \mathrm{~Hz}, \mathrm{H}_{2}\right.$ and $\mathrm{H}_{6}$ of $\left.\mathrm{Ph}\right), 8.26-8.15\left(\mathrm{~m}, 5 \mathrm{H}, \mathrm{H}_{3}\right.$ and $\mathrm{H}_{5}$ of $\mathrm{Ph}, \mathrm{H}_{3}$, $\mathrm{H}_{6}$, and $\mathrm{H}_{9}$ of $\mathrm{BQ}$ ), 7.62-7.59 (m, 2H, $\mathrm{H}_{7}$ and $\mathrm{H}_{8}$ of BQ), 2.67 (s, 3H). MS (ESI) cacld for $\mathrm{C}_{21} \mathrm{H}_{15} \mathrm{NO}$ $[\mathrm{M}+1] 298$, found 298. Anal. calcd for $\mathrm{C}_{21} \mathrm{H}_{15} \mathrm{NOC}, 84.82 ; \mathrm{H}, 5.08 ; \mathrm{N}, 4.71$. Found C, 84.59; H, 5.14; N, 4.78. Benzo[g]quinoline (4): $33 \%$.

1,3,5-Tris(benzo[g]quinolin-2-yl)benzene (3e). Pale yellow needles [53\%, $R_{\mathrm{f}}=0.4, \mathrm{CH}_{2} \mathrm{Cl}_{2}$ : EtOAc (3:1)]: mp 352-354 ${ }^{\circ} \mathrm{C} . T \mathrm{c} 284.23{ }^{\circ} \mathrm{C} .{ }^{1} \mathrm{H}-\mathrm{NMR}\left(250 \mathrm{MHz}, \mathrm{CDCl}_{3}\right) \delta 9.31$ (s, 3H, $\mathrm{H}_{2}, \mathrm{H}_{4}$, and $\left.\mathrm{H}_{6} \mathrm{of} \mathrm{Ph}\right)$, $8.90\left(\mathrm{~s}, 3 \mathrm{H}, \mathrm{H}_{10}\right.$ of $\left.\mathrm{BQ}\right), 8.52$ (d, $3 \mathrm{H}, J=8.7 \mathrm{~Hz}, \mathrm{H}_{4}$ of $\left.\mathrm{BQ}\right), 8.47$ (s, $3 \mathrm{H}_{1} \mathrm{H}_{5}$ of BQ), 8.25 (d, $3 \mathrm{H}$, $J=8.8 \mathrm{~Hz}, \mathrm{H}_{3}$ of BQ), 8.15-8.06 (m, 6H, $\mathrm{H}_{6}$ and $\mathrm{H}_{9}$ of $\left.\mathrm{BQ}\right), 7.56-7.53$ ( $\mathrm{m}, 6 \mathrm{H}, \mathrm{H}_{7}$ and $\mathrm{H}_{8}$ of BQ). MS (ESI) cacld for $\mathrm{C}_{45} \mathrm{H}_{28} \mathrm{~N}_{3}[\mathrm{M}+1]$ 610, found 610. Anal. calcd for $\mathrm{C}_{45} \mathrm{H}_{27} \mathrm{~N}_{3} \mathrm{C}, 88.64 ; \mathrm{H}, 4.46$; $\mathrm{N}, 6.89$. Found C, 88.89; H, 4.38; N, 6.79. Benzo[g]quinoline (4): $28 \%$.

\section{Conclusions}

In conclusion, (benzo[g]quinolin-2-yl)benzene, 2-(benzo[g]quinolin-2-yl)pyridine, 1,3-di- and 1,3,5-tri(benzo[g]quinolin-2-yl)benzenes were prepared by Friedländer reactions of 3-aminonaphthalene-2-carbaldehyde with the corresponding acetylbenzenes and 2-acetylpyridine. All compounds display three intense absorption bands in the ultraviolet region (205-400 nm) with extinction coefficients $(\varepsilon)$ of $\sim 10^{5}$. Excitation of the absorbance in the region 253-294 nm showed greenish blue light emissions in the range of 470-488 nm. All the compounds showed crystalline nature and good thermal stabilities. Studies on the formation of Ir complexes and their properties are in progress and will be reported in the near future.

\section{Supplementary Materials}

Supplementary materials $\left({ }^{1} \mathrm{H}\right.$ - and ${ }^{13} \mathrm{C}-\mathrm{NMR}$ spectra of the selected compounds) can be accessed at: http://www.mdpi.com/1420-3049/19/8/12842/s1.

\section{Acknowledgments}

Financial support from National Research Foundation (2010-0012473) is gratefully acknowledged. MK is a recipient of BK scholarship (2013) from College of Pharmacy, Choongbuk National University.

\section{Author Contributions}

MK performed the practical work and participated in manuscript writing. YJ planned the experiments, supervised and wrote the paper.

\section{Conflicts of Interest}

The authors declare no conflict of interest.

\section{References and Notes}

1. Evans, J.C.W.; Allen, C.F.H. 2-Phenylpyridine. Org. Syn. 1938, 18, 70. 
2. Taiju, T.; Wei, H. Recent advances in multicolor emission and color tuning of heteroleptic iridium complexes. Isr. J. Chem. 2014, 54, 885-896.

3. Zhou, G.; Wong, W.-Y.; Yang, X. New design tactics in OLEDs using functionalized 2-phenylpyridine-type cyclometallates of iridium(III) and platinum(II). Chem. Asian J. 2011, 6, 1706-1727.

4. Tamayo, A.B.; Alleyne, B.D.; Djurovich, P.I.; Lamansky, S.; Tsyba, I.; Ho, N.N.; Bau, R.; Thompson, M.E. Synthesis and characterization of facial and meridional Tris-cyclometalated iridium(III) complexes. J. Am. Chem. Soc. 2003, 125, 7377-7387.

5. Tsuboyama, A.; Iwawaki, H.; Furugori, M.; Mukaide, T.; Kamatani, J.; Igawa, S.; Moriyama, T.; Miura, S.; Takiguchi, T.; Okada, S.; et al. Homoletptic cyclometalated iridium complexes with highly efficient red phosphorescence and application to organic light-emitting diode. J. Am. Chem. Soc. 2003, 125, 12971-12979.

6. Baranoff, E.; Yum, J.-H.; Graetzel, M.; Nazeeruddin, M.K. Cyclometallated iridium complexes for conversion of light into electricity and electricity to light. J. Organomet. Chem. 2009, 694, 2661-2670.

7. Lowry, M.S.; Bernhard, S. Synthetically tailored excited states: Phosphorescent, cyclometalated iridium(III) complexes and their applications. Chem. Eur. J. 2006, 12, 7970-7977.

8. Yang, C.-H.; Cheng, Y.-M.; Chi, Y.; Hsu, C.-J.; Fang, F.-J.; Wong, K.-T.; Chou, P.-T.; Chang, C.-H.; Tsai, M.-H.; Wu, C.-C. Blue-emitting heteroleptic iridium(III) complexes suitable for high-efficiency phosphorescent OLEDs. Angew. Chem. Int. Ed. 2007, 46, 2418-2421.

9. Ulbricht, C.; Beyer, B.; Friebe, C.; Winter, A.; Schubert, U.S. Recent development in the application of phosphorescent iridium(III) complex systems. Adv. Mater. 2009, 21, 4418-4441.

10. Igarashi, T.; Kimura, K.; Nii, K. Light-Emitting Material Comprising Orthometalated Iridium Complex, Light-Emitting Device, High Efficiency Red Light-Emitting Device, and Novel Iridium Complex. U.S. Patent Application US20010019782, 6 September 2001.

11. You, Y.; Huh, J.O.; Kim, K.S.; Lee, S.W.; Kim, D.; Park, S.Y. Comment on "aggregation-induced phosphorescent emission (AIPE) of iridium(III) complexes": Origin of the enhanced phosphorescence. Chem. Commun. 2008, 3998-4000.

12. Adachi, C.; Baldo, M.A.; Thompson, M.E.; Forrest, S.R. Nearly $100 \%$ internal phosphorescence efficiency in an organic light-emitting device. J. Appl. Phys. 2001, 90, 5048-5051.

13. Wu, H.; Yang, T.; Zhao, Q.; Zhou, J.; Li, C.; Li, F. A cyclometalated iridium(III) complex with enhanced phosphorescence emission in the solid state (EPESS): Synthesis, characterization and its application in bioimaging. J. Chem. Soc. Dalton Trans. 2011, 40, 1969-1976.

14. Chirdon, D.N.; Transue, W.J.; Kagalwala, H.N.; Kaur, A.; Maurer, A.B.; Pintauer, T.; Bernhard, S. $\left[\operatorname{Ir}\left(\mathrm{N}^{\wedge} \mathrm{N}^{\wedge} \mathrm{N}\right)\left(\mathrm{C}^{\wedge} \mathrm{N}\right) \mathrm{L}\right]^{+}$: A new family of luminophores combining tunability and enhanced photostability. Inorg. Chem. 2014, 53, 1487-1499.

15. Lamansky, S.; Djurovich, P.; Murphy, D.; Abdel-Razzaq, F.; Kwong, R.; Tsyba, I.; Bortz, M.; Mui, B.; Bau, R.; Thompson, M.E. Synthesis and characterization of phosphorescent cyclometalated iridium complexes. Inorg. Chem. 2001, 40, 1704-1711.

16. Shin, I.-S.; Kim, J.I.; Kwon, T.-H.; Hong, J.-I.; Lee, J.-K.; Kim, A. Efficient electrogenerated chemiluminescence from bis-cyclometalated iridium(III) complexes with substituted 2-phenylquinoline ligands. J. Phys. Chem. 2007, 111, 2280-2286. 
17. Qiao, J.; Duan, L.; Tang, L.; He, L.; Wang, L.; Qiu, Y. High-efficiey orange to near-infrared emissions from bis-cyclometalated iridium complexes with phenyl-benzoquinoline isomers as ligands. J. Mater. Chem. 2009, 19, 6573-6580.

18. Zhang, G.; Zhang, H.; Gao, Y.; Tao, R.; Xin, L.; Yi, J.; Li, F.; Liu, W.; Qiao, J. Near-infrared-emitting iridium(III) complexes as phosphorescent dyes for living cell imaging. Organometallics 2014, 33, 61-68.

19. Etienne, A. Action of phenylmagnesium bromide on 1-azaanthracene. Comptes Rend. 1944, 219, $622-624$.

20. Bergstrom, F.W.; McCallister, S.H. The preparation of 2-alkyl and 2-aryl pyridines and quinolines by the Grignard reaction. J. Am. Chem. Soc. 1930, 52, 2845-2849.

21. Staehelin, A. Synthesis of $\alpha$-azaanthracenes starting from linear benzisatin. Comptes Rend. 1951, 233, 262-264

22. Yao, M.; Inoue, H.; Yoshioka, N. Novel aromatic $N$-oxyl radical based on the benzo[g]quinoline skeleton: Synthesis and intermolecular ferromagnetic interaction. Chem. Phys. Lett. 2005, 402, 11-16.

23. Huo, Z.; Gridnev, I.D.; Yamamoto, Y. A method for the synthesis of substituted quinolones via electrophilic cyclization of 1-azido-2-(2-propynyl)benzenes. J. Org. Chem. 2010, 75, 1266-1270.

24. Taffarel, E.; Chirayil, S.; Thummel, R.P. Synthesis and properties of ligands based on benzo[g]quinoline. J. Org. Chem. 1994, 59, 823-828.

25. Liang, J.; Cha, H.; Jahng, Y. Synthesis and properties of annulated 2-(azaar-2-yl)-and 2,2'-di(azar-2-yl)-9,9'-spirobifluorens. Molecules 2013, 18, 13680-13690, and references therein.

26. Haginiwa, J.; Higuchi, Y.; Ikeda, S. Reactions concerned in tertiary amine $N$-oxides XIII. reactions of benzo[f, $h$ and $g]$ quinoline and acridine with aromatic amine $N$-oxides. Yakugaku Zasshi 1979, 99, 1181-1185, in which 3ab was prepared by a reaction of benzo[g]quinoline and pyridine- $N$-oxide in $0.3 \%$ yield.

27. Krapcho, A.P.; Gilmor, T.P. General preparative route to benzo[g]quinoline (1-azaanthracenes). J. Heterocycl. Chem. 1999, 36, 445-452.

28. Rahman, A.F.M.M.; Jahng, Y. Synthesis and properties of benzo[b]-1,10-phenanthrolines and their ruthenium(II) complexes. Heteroat. Chem. 2007, 18, 650-656.

29. Rahman, A.F.M.M.; Kwon, Y.; Jahng, Y. Friedländer reactions of triacetylmethane: Unusual distribution of products. Heterocycles 2005, 65, 2777-2782.

30. Huu-Hoi, N.P.; Perin, F.; Jacquignon, P. Nitrogen heterocyclic analogs of polyaryls. J. Heterocycl. Chem. 1965, 2, 7-10.

Sample Availability: Samples of the compounds $\mathbf{3 a a}, \mathbf{3 a b}, \mathbf{3 c}, \mathbf{3 e}, \mathbf{4}$, and $\mathbf{5}$ are available from the authors.

(C) 2014 by the authors; licensee MDPI, Basel, Switzerland. This article is an open access article distributed under the terms and conditions of the Creative Commons Attribution license (http://creativecommons.org/licenses/by/3.0/). 